\title{
The Spillover Effect of the Consumerism Trap: Analyzing Nauru's Resource Curse Phenomenon to Voluntary Simplicity Prescriptions for Nauruans
}

\section{Firsty Chintya Laksmi Perbawani}

Firsty Chintya Laksmi Perbawani

$\begin{array}{lcl}\text { Affiliation } & : & \text { Universitas Pembangunan } \\ & \text { Nasional Veteran Jawa } \\ & \text { Timur } \\ \text { City } & : & \text { Surabaya } \\ \text { Country } \quad: & \text { Indonesia } \\ \text { Email } \quad: & \\ \text { Firsty.chintya.hi@upnjatim.ac.id }\end{array}$

History

Submission : 26 Juni 2021

Review : 4 Juli 2021

Completed

Accepted : $\quad$ 10 July 2021

Available $\quad: \quad 10$ July 2021

Online

DOI :

10.51413/jisea.Vol2.Iss1.2021.91-104

\section{Copyright}

This is an open access article distributed under the term of the creative commons attribution 4.0 international licence

\begin{abstract}
The flow of people and goods with the existence of globalization brought a new pattern of life. People tend to change their consumption pattern from fulfilling the basic needs to becoming consumerism; a behavior of buying goods and services that are more concerned with what is desired than what is needed. This phenomenon established a new problem called the consumerism trap; a dilemmatic situation in which we want to dismiss consumerism but the impact it causes is even more detrimental. The upcoming question will be about, is consumerism trap is increasingly escalated with globalization in this contemporary era? The author argues that globalization accelerates the pattern of consumerism. This paper portrays Nauru as the best example to support the author's argument because it shows that Nauruans are complacent with their wealth of phosphate resources, then become lazy, dependent, and finally adopt a consumerism lifestyle. It made Nauruans trapped in spillover problems, like environmental degradation, obesity, financial flows by build shell banks, etc. To sum up, the era of globalization increasingly giving space for people to be trapped in the consumerism trap; moreover, society does not see the continued implications of consumerism. By analyzing Nauru, we learned how globalization accelerates consumerism and creating spillover effects for the country. At the end, the author gives a prescription to solve this problem by doing voluntary simplicity as the antithesis of consumerism.
\end{abstract}

Key Words: consumerism trap, Nauru, obesity, shell bank, voluntary simplicity

\section{Cite this article :}

Perbawani, F. C. L. (2021). The Spillover Effect of the Consumerism Trap: Analyzing Nauru's Resource Curse Phenomenon to Voluntary Simplicity Prescriptions for Nauruans. Journal of International Studies on Energy Affairs, 2(1), 91-104. https://doi.org/10.51413/jisea.Vol2.Iss1.2021.91-104 


\section{INTRODUCTION}

Globalization is the most precise term to depict the rapid flows of cross-border free movement, such as people, goods, services, and capital. All of those movement has promoted enormous potential responses, including the consumerism agenda. According to Amitai Etzioni (2004, p. 407) there has been a transition pattern where initially, the consumption only to bind the basic needs such as food, clothes, and shelter; now, to be consumerism, the obsession with achieving ever-higher levels of consumption, including a significant amount of ostentatious purchase of prestige items. The key issue that must be faced is that globalization is hastening the rise of consumerism, and the global community as a whole has been unaware of the consequences of this behavior (Dugis, 2018). Individuals who embrace consumerism will develop the mentality that people seeking money or commodities are more important than helping others who are in need. Furthermore, individuals that pursue consumerism are more prone to environmental damage since they tend to use resources more than other societies (Etzioni, 2004, p. 408). That is the implication that sometimes eludes the calculation of a society with a high degree of consumption, much more the other globalization-related effects that will occur.

Thus, in this contemporary era, the world is faced with a dilemmatic situation, namely the presence of a 'consumerism trap' where we seek to end consumerism but the impact is much more damaging on the other side. If empirical studies are to be heeded, the instance that best describes this phenomenon is what occurred in Nauru. The author chose this country because it was formerly one of the world's highest-income countries and might be regarded as a highly wealthy country. However, they are slowly has become engulfed in consumerism, resulting in poverty and environmental degradation to $90 \%$ of its region, as well as difficulties from various other aspects (Pollock, 2014, pp. 108-9). Then back to the background, research question arises: "whether the consumerism trap is becoming more pronounced (increasingly escalating) in this contemporary era as a result of globalization?"

\section{Thesis Argument}

According to the author, globalization hastens the pattern of consumerism. This is exacerbated by the fact that consumerism has become a cultural norm in society. Capitalism and industrialization are other aspects that contribute to the emergence of consumerism, according to the author, because consumerism is the result of excessive ownership. Not only that, but consumerism is human nature, even from a psychological standpoint, beginning with the notion that great riches in a 
capitalistic and consumptive culture can 'purchase' status, which might strengthen the assumption of a more successful life. That excessive ownership and consumptive consumerism correlated with many spillover effects afterward. To analyze this, the author will look at what happened in the country of Nauru, which was once quite wealthy but has now fallen into poverty due to the consumerism of the people (Nauruans). Nauru must deal with issues in a variety of other areas; in other words, there is a spillover effect. Nauruans' consumerism is not simply a complacent lifestyle as a result of the wealth of phosphate mining, but it also extends to environmental and health issues as a country with the highest obesity prevalence in the world.

\section{METHOD AND THEORETICAL REVIEW}

This research employs qualitative data analysis, in which the author refines and classifies the data so that it can support the answer to the research question; presents and interprets the data in the form of narrative text; and finally, draws the proposition plot to answer the research question (Kawulich, 2004, pp. 101-3). The design study of this research will be the theoretical framework; results and discussions; then, the conclusion. This research incorporating how the consumerism trap is inseparable from the existence of globalization. Later, it can be seen with depth-analysis on how the empirical facts that happened to Nauru prove that the consumerism trap brought the spillover effect for the country.

Begin by considering the theoretical framework, as it can provide a lens through which the data can be viewed, as well as assisting the researcher in situating the results within the theory, which can assist in the understanding of the data within that theoretical perspective. Starting with the debate on the correlation of globalization and consumerism; how consumerism transitioning into global desire; how 'needs' are transitioning in this globalized era.

\section{The spectrum of Globalization and Consumerism Problems}

Consumption, according to Andrea Migone (2004, p. 1), cannot be detached from what the market has to offer and people's ability to spend. Consumption is a necessary component of human social and biological existence. The author deduces from that statement that while the market is expanding, particularly in this period of globalization; new techniques to entice consumption will emerge, and the market will continue to strive to satisfy the public. Likewise, Migone (2004, p. 2) argues that capitalism's inclination is more capable of manipulating and blurring the boundary between what is needed and what is desired. According to Dugis (2018), 
consumerism is more oriented to 'satisfaction,' where style is more essential than substance, image is more significant than reality, and perception is more important than performance, in accordance with Migone's assertion. The problem spans not just human personal choices to engage in consumption, but it also impacts the global sphere as a result of globalization.

If it is related to globalization, we must not count out the economic phenomena, since the author argues that capitalism and industrialization are also variables that foster the creation of consumerism. To back that argument up, the author might refer to Migone's (2004, p. 5) article which claims that consumerism is indeed the spirit of modern capitalism. Migone argued that in the modern era, the market has begun to shift; it has evolved into a space where economic players may choose what to purchase, sell, or provide. Capitalism occurs when both sellers and buyers choose what the market requires; where, in general, the seller will give what the buyer desires, and the buyer, in turn, selects what he desires based on characteristics that 'satisfy' his desires rather than what is required. Because the market may now determine the framework of trade and construct the socio-institutional side, it can be viewed as more than just an arena for trading commodities and services (Weber 1992, Elliot 200, Smith 1963, in Migone 2004, p. 6). As a result, exchange and trade, which are nothing more than descriptions of modern capitalism, may be viewed as a gradual growth of consumerist character in society.

The dominating method of economic exchange in today's world is modern capitalism. Individualistic principles are indisputable in capitalist epistemology; economic actors operate in such a way as to maximize individual satisfaction (Migone, 2004, p. 7). The market, as well as the events that occur, will unavoidably be drawn into the consumerism cycle. Furthermore, the consumerism cycle has an impact on cultural aspects that might link to and influence human generations from a socio-psychological standpoint. This has a wide impact since it is linked to a way of life that spreads across a region, not only within a country. Consumption, which began as a means of meeting fundamental requirements, has evolved into something more. People buy what the market has to offer to get social recognition, and some items with specific brands might have high symbolic value.

Following this consumption, there will be other higher-priced consumptions. These phenomena have the potential to develop a culture because it will satisfy a person's psychological needs (Baudrillard in Migone, 2004, p.9). For the author, consumption has a broad-spectrum problem since it may give rise to a hedonistic character, in which a product or service acquired by customers can be utilized as a social status indicator. This does not only influence one person; other persons will 
strive for greater attention and live expensive, complacent, and consumptive lives to achieve a particular level of 'satisfaction'.

\section{Transition because of Consumerism: The Global Transformation of Desire}

When the consumerism lifestyle of a country's citizens has an impact on economic activity, particularly in terms of mass consumption, consumerism becomes a global problem. The article of Peter N. Stearns (2006, p. 15) with two main arguments, can illustrate the presence of a transition because of consumerism. First, the development of consumer apparatus was in the past, sellers competed to beautify their shop's window display, currently, sales are no longer limited to physical stores and have moved to virtual marketplaces. Advertisements are constantly encouraged, whether on television, radio or on personal gadgets. As a result, people are increasingly unable to determine what they require, and they are lured by the urge to obtain the promoted items or services. Second, the emergences of the needs, where the needs are growing. For instance, people did not require a gadget in the past, but in the age of globalization, when communication and technology must be fast, everyone has at least one device (Stearns, 2006, pp. 17-20). This also proves that inevitably there is a global drive to transform what is called desire which is a necessity in this contemporary era. The author agrees with both of Stearns' arguments since globalization will at the very least push the global community to communicate with one another; the interchange of information is extremely fast; some commodities or services may easily 'booming' from one country to another around the world. Moreover, coupled with advertisements that are increasingly attractive and frequent, consumerism is inevitable and escalates.

\section{The Evolution of 'Needs' to 'Hierarchy of 5 Needs'}

In addition to that, according to Needs Theories, consumerism is also escalating in the contemporary era as people's perceptions of what constitutes a need evolve. William James added that in the past, the construction of needs was solely based on satisfaction in meeting fundamental requirements for food, clothes, and shelter; however, James claims that the level of need today has its hierarchy (Ward \& Lasen, 2009, pp. 2-3). The 'material self,' or the satisfaction of what is connected to one's body, such as instinct and appetite, love of jewelry, desire to acquire property, and so on, is located at the bottom. Then there is the 'social self,' or the satisfaction of desires related to receiving recognition from others, such as the want to be admired, the pursuit of honor, or the goal to achieve a high degree of intelligence. At the top, 
the 'spiritual self,' namely the fulfillment of what is related to belief, which is a combination of the individual's inner subjectivity and also the human psychic senses, which is intended as a person's sensory and emotional perception; such as religious aspirations, moral sense, conscience sensitivity, to the sense of inferiority or guilt.

Those James' three levels were further elaborated by Abraham Maslow which later his theory on consumerism is still widely accepted today. It should be mentioned that Maslow created his theory by studying the phenomena that occur in a company's workforce, after which he recognized various incentives to further enhance the 'needs' of these people. As illustrated in the figure below, the results of his research are also summarized in five stages or levels placed in a tiered pyramid, widely known as Maslow's five needs model:

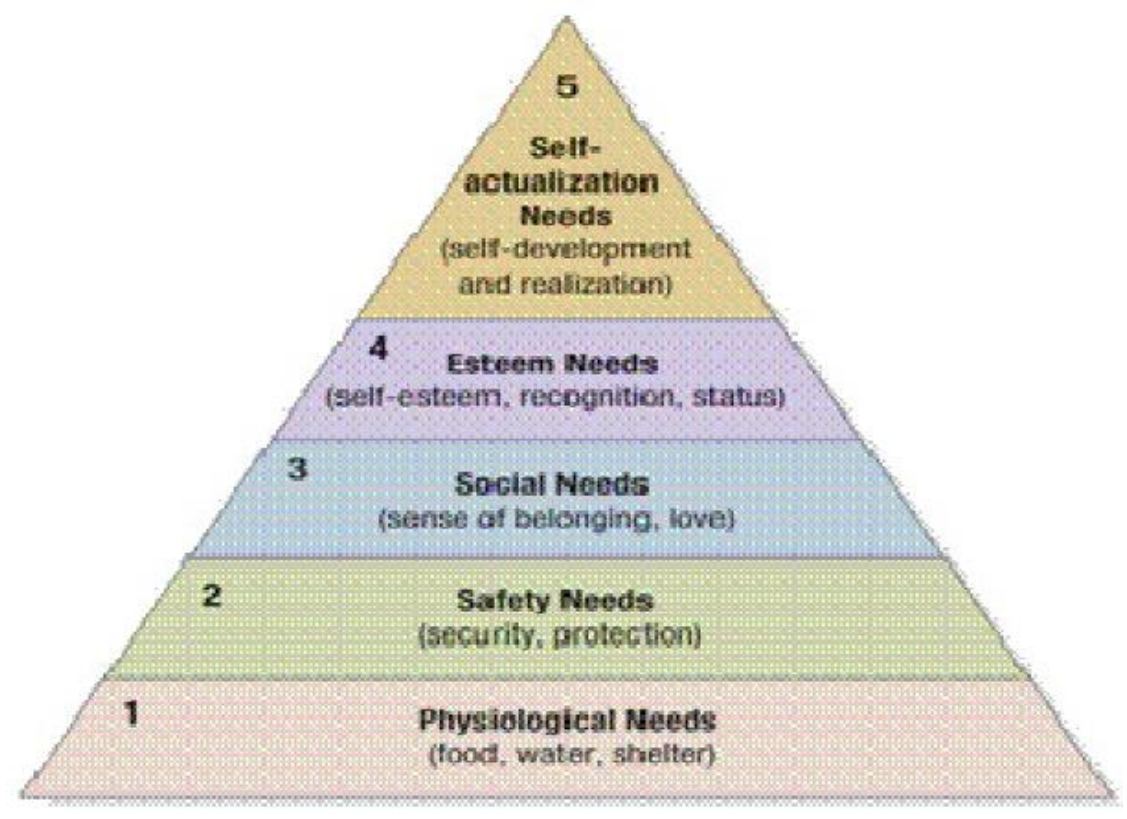

Figure 1. Maslow's hierarchy of 5 needs

Source: (Ward \& Lasen, 2009, p. 4)

Maslow views the requirements of life to be the most important of all current 'needs', as seen in the figure above since if they are not satisfied, an individual will not grow into other sorts of needs. Those survival needs are classified as Physiological Needs and being the first and foremost by Maslow. At the second level is Safety Needs where humans need to be secured and well-protected from any threat. Followed by Social Needs such as feeling to be loved and socialize well. The fourth level is Esteem Needs which is concerned with how a person requires the value of status, selfesteem, and acknowledgment from his surroundings. The Self-actualization Needs 
which comprise the need for self-development and realization, are at the top of the hierarchy, or the fifth level (Ward \& Lasen, 2009, p. 4). Maslow divides the five needs model into two unequal parts, with the first four stages or levels focusing on "having" or "materialistic" needs, while the last stage is referred to as "being" since it is nonmaterialistic and holistic. It turns out that as globalization and science progress, there are new 'needs,' particularly Aesthetic Needs, which are the actualization of a sense of beauty, balance, and shape. This may be observed in the community's desire to preserve physical attractiveness through activities like fitness routines, yoga, cosmetic surgery, dieting instructors, and the purchase of high-end cosmetics (Ward \& Lasen, 2009, pp. 6, 16).

From both James' and Maslow's theories, the author sees that humans have a core nature and desire to continue to meet their needs. As globalization blurs boundaries and accelerates information, the classification of 'needs' evolves as well. As a result, humans get complacent, which leads to further consequences. There is an overuse of natural resources in general, which influences the environment. This, according to the author, demonstrates how consumerism has an impact not just on individuals but also on countries. As a result, the author will attempt to demonstrate an empirical instance that demonstrates the link between consumerism's trap and the existence of globalization.

\section{RESULT AND DISCUSSION}

To results and discussion will portray how Nauru can be used as the empirical evidence where the resource curse is happening because of the consumerism trap. At first, Nauru is lulled by its phosphate resources. Then changing the pattern of their life, the spillover effect (especially environmental degradation) happened, until how Government Money-making Schemes be carried out.

\section{Empirical Evidence: Phosphate, Nauru's Wealth Source}

Firstly, to prove the theoretical framework and arguments presented above, the author chooses to examine consumerism in Nauru, a country located between Australia and Hawaii. Nauru, the smallest South Pacific country with a total area of only 21 square kilometers and a population of 11,200 people, has a very beautiful history. This is because phosphate resources cover nearly $70 \%$ of Nauru's territory. According to history, Nauru, which was once a British colony, became a Guano bird colony, and the bird droppings accumulated, settled, and eventually became phosphate, which serves as plant fertilizer (Aldino, 2016). Because of its truly 
abundant phosphate wealth, Nauru was finally able to become a small rich country with a high Gross Domestic Product (GDP) achievement in 1981, Nauru already had a per capita income of 17,000 US dollars. Later that year, Nauru's income reached US $\$ 2.5$ billion, making it the world's highest income per inhabitant (Aldino, 2016).

Phosphate mining began in 1906 when the Nauruan population was less than 1000 people. During the civil war, many traders, primarily from Germany, were keen on this phosphate-rich island. What happened after Nauru became a German colony? Germany proposed a centralized organizational pattern for the administration of Nauru; however, the Nauruans rejected this because they preferred to maintain their traditional structure. This structure emphasizes tribal, district, and family mobility leadership based on loyalty. When the British Phosphate Commissioners introduced new deputies to manage existing mines in 1927, tribal organizations were reviewed further (Pollock, 2014, p. 19). Through the Nauru Local Government Council, the Nauruans established a structure that had begun to be less hierarchical because the ruling and middle classes (Temonibe and Amenkenaname classes) were higher than the immigrant tribes (Itsio class) in 1952. It can be seen here that Nauru has historically had its social system with twelve tribes divided into three classes. The author believes that this fact can amplify the sense of being in a 'better' position than other communities. It is unavoidable that the structure of Nauruan society will inevitably give its own 'need' for social recognition, especially given the state of Nauru's excess phosphate wealth.

\section{Nauruans' Lifestyle Change: High Consumerism}

The advantages of phosphates appear to have made the Nauruans complacent even before independence, as a laboratory study was carried out in Sydney for the first time in 1900, attracting the attention of the world because it turned out that the phosphate content was lime. At the time, the most expensive type of phosphate ore was lime-type phosphate ore. As previously stated by the author, a Pacific Phosphate Company was granted the right to mine Nauru by Germany in 1906, when Nauru was still under German control (Pillsrisetti, 2007, p. 4). It did not give Nauruans more authority over phosphate mining until after they gained full independence on January 31, 1968. Nauru inevitably became a wealthy and wellknown country. Furthermore, the government does not levy taxes, all access to education and health care is free, food subsidies are provided, and those who wish to further their education abroad are given scholarships. There are no longer any poor people on Nauru, and as a result, the Nauruan way of life has shifted to one of high consumerism. Because they were too wealthy, Nauruans eventually chose to import Lamborghinis and luxury commercial planes. Nauruans' lifestyle is 
becoming increasingly chaotic because, despite the government's appointment of 80 percent of the workforce as civil servants, many Nauruans choose to leave their jobs and vacation abroad. Because it had become too spoiled, the government was forced to import workers from Australia, China, and neighboring countries such as Kiribati and Tuvalu (Aldino, 2016). Nauruans' minds have been instilled with high consumerism because they believe that even if they do not work, they can still live in luxury and find fulfillment by throwing parties every day. Nauru appears to have been in that situation: the locals were unsure what to invest in and preferred to use dollars as toilet paper.

The author believes that this demonstrates that the identity of the Nauruans, which is a proliferation of Micronesia and Polynesia, can no longer fight for themselves like traditional era warriors; instead, they become complacent with the wealth they obtain and engage in high consumerism, even though they do not see how capitalism affects them because they open their resources to the needs of Australia and other countries. The author's argument is bolstered by Nancy J. Pollock's (2014, p. 108) article titled "Nauru Phosphate History and the Resource Curse Narrative", which claims that Nauru is one example of the negative impact of cash dependence as a component of capitalism.

\section{The Spillover Effect of Nauru's Consumerism: Environmental Degradation and World's Highest Obesity}

\section{Rate}

Nauru's consumerism and reliance on phosphates did not last long; sources of phosphate were depleted decades later, in the 1990s. Phosphate mining has rendered nearly $80 \%$ of the interior of the island of Nauru uninhabitable (wasteland), and this phenomenon has forced the island's inhabitants to relocate to the island's outskirts (Pollock, 2014, p. 114). The Nauru region has devolved into a desolate jagged desert, as depicted below. 


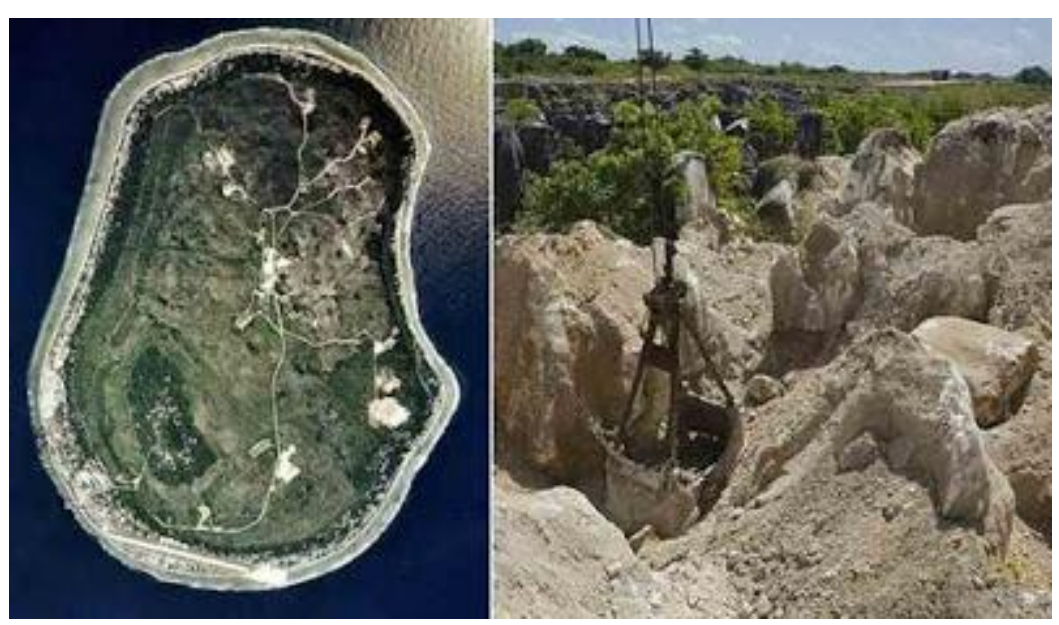

Figure 2. The Changing of Nauru's Environment

Source: (Aldino, 2016)

The figure demonstrates how excessive exploration to stimulate Nauru's consumerist lifestyle has a spillover effect on other dimensions, in this case, the environment. Environmental degradation has a significant impact; even the environmental organization Greenpeace has condemned the damage caused by the Nauruan government's negligence in conducting excessive phosphate exploration. However, the Government of Nauru has demanded compensation from the United Kingdom, Australia, and New Zealand for damage to Nauru's environment, as these countries have numerous mining companies on the island. Following an out-ofcourt settlement, Australia paid the government of Nauru US\$2.5 million over 20 years, while the United Kingdom and New Zealand paid US\$1.2 million (Aldino, 2016). This number is not proportional if it is being compared with the environmental degradation that happened to Nauru.

Another issue that must be addressed is Bloom's BMI, and until 2017, WHO noted that Nauru had the world's highest obesity rate. According to the Global Nutrition Report, the obesity rate for adult males in Nauru reached 39.7 percent, which is still four times the global average. The obesity crisis in Nauru is the result of several factors, including history, economy, and even culture. When the country began to collapse economically, this over-mining destroyed almost all of the island's domestic agriculture. Traditional foods such as coconut and other fresh vegetables are no longer available, leaving only fish as the sole source of food in Nauru. What are the consequences? The country is entirely reliant on imported food. Even so, according to MIT's Observatory for Economic Complexity research, Nauru imports only $5 \%$ of vegetable products, while the remaining $12 \%$ are other food ingredients that are generally unhealthy due to their artificial and sweet ingredients (Gopalan, 
2017). One could argue that Nauru imports a lot of unhealthy food, endangering the health of its citizens and possibly contributing to obesity.

The government faces difficulties with type 2 diabetes mellitus, the liver, and the kidney. Obesity occurs because Nauru has a problem with alcohol consumption and tobacco use is widespread. This pattern has become ingrained as a result of the legacy of past consumerism. Additionally, the economic downturn has conditioned Nauruans to rely on staple foods such as white rice, instant noodles, soda, and whatever food and beverages are available in cans. Amy McLennan, an anthropologist from Oxford, stated that this is not because Nauruans are unaware of the dangers of obesity; on the contrary, they are aware that numerous school programs teach about nutrition and physical activity, but these are rarely implemented by Nauruans (Hallett, 2015). The government is attempting to address it by encouraging people to walk at least three miles per week. However, this is less effective at reducing Nauru's obesity rate. Inevitably, when these two economic trends are combined, Nauru finds itself confronted with the current obesity crisis. Due to environmental degradation caused by previous resource exploitation, the state of Nauru has been forced to import the majority of its food, and economic stagnation has forced it to purchase the cheapest food available, which is unquestionably unhealthy (Gopalan, 2017).

\section{What happened next: Government Money-making}

\section{Schemes?}

As the country's security was jeopardized, Nauru began to believe that the country could survive and make money by leveraging cooperation with other countries. First, in the early 2000s, Nauru implemented a money-making scheme by exporting coffee tables to the West and also licensing Nauru's telephone code for sex telephone lines. Nauru has used its UN membership to recognize the Republic of Abkhazia and South Ossetia, for which it has been awarded a reward of up to \$25 million US dollars. Then, it allows for the establishment of a Shell bank in Nauru, where all countries can transact and are not subject to certain transaction records (Jegulo, 2017). In 2000, the Russian mafia owned nearly 400 Shell banks, and money laundering occurred, which became Nauru's responsibility due to unclear banking laws. Furthermore, Nauru raised the visa application fee for foreign journalists from US $\$ 200$ to US $\$ 8,000$ in 2015 (Jegulo, 2017). Nauru was also paid by Australia in 2001 to house 434 refugees in exchange for nearly US $\$ 10$ billion over the previous four years. The most recent development occurred on 7 August 2018, when the Government of Nauru purposefully destroyed refugee tents before 
the start of the Pacific Islands Forum in Nauru on 1 September. What is the purpose of this? Apparently, Nauru has not treated refugees properly, and money from Australia has been misappropriated to rebuild Nauru's economy (Rintoul, 2018). The following figure showed the Nauru Government's refugee camps:

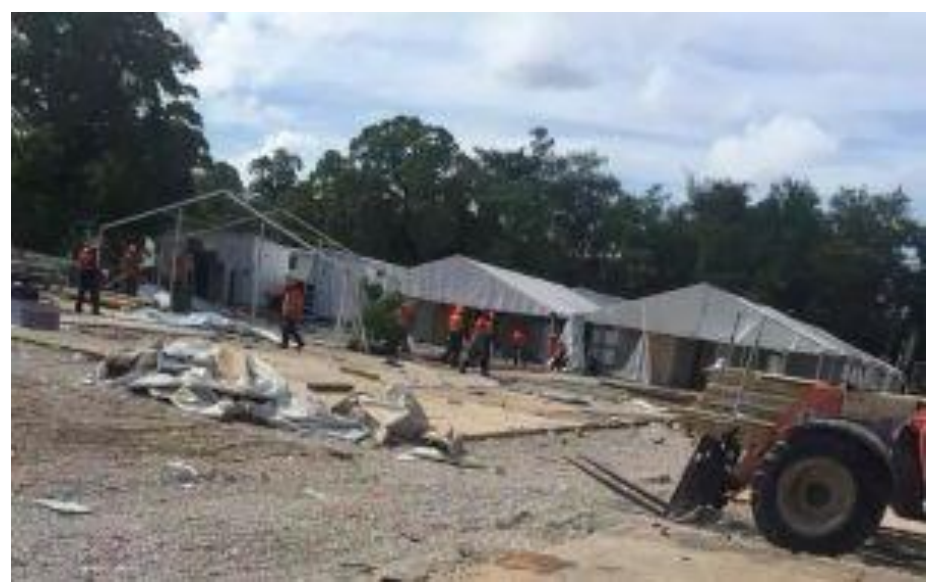

Figure 3. Nauru's Refugee Camps

Source: (Rintoul, 2018)

The figure clearly shows that the refugees are not well cared for by the Nauru government, as they are only given a place to live in moldy tents. The government of Nauru constructed a fortress to ensure that there would be no contact between the media and the refugees during the 2018 Pacific Islands Forum. The refugee camps were purposefully relocated in the hope of preventing refugees from complaining, and there is no international media coverage of this reality. Naturally, with the hope that Nauru's global reputation will be preserved.

The government makes these efforts to dredge and earn money. However, for the rest of the world, Nauru is merely a client state of Australia in this contemporary era. The author's point is that Nauru is already irrational and endangering the security of his own country. This is all due to consumerism and the extravagant acts of the Nauruans, who are unable to escape the greed of mining for phosphate resources, with the consequences of environmental damage, so that the country's reliance on its core income has disappeared completely. The economy was destroyed, and now the Nauru Government can carry out this scheme without regard for the country's security. 


\section{Author's Prescription: Voluntary Simplicity and Legal}

\section{Protection}

According to the author, every individual Nauruan must raise awareness, at the very least understanding that consumerism, as it is commonly practiced, has a negative impact. This is based on what Etzioni (2004, p. 410) proposes, namely the implementation of voluntary simplicity (VS), a term that is the polar opposite of consumerism and is defined as an effort to voluntarily reduce or reduce a simpler lifestyle. It can be done in three stages, beginning with the simplest and progressing to the most advanced, namely: (1) moderate level, beginning downshifters or reducing simple things; (2) advanced level, reducing complex things; and (3) advanced level, reducing complex things. Dress more modestly, for example; (2) at a high level, begin to restructure life patterns. For example, changing the belief that happiness in the family is far more important than financial wealth; (3) holistic level, by making dramatic changes to the overall level and consumption patterns. Consider the growing number of simple living movements in various countries. VS will provide equality. People's basic thinking can become more rational and willing to share if they are consciously willing to do VS because simplicity is the key to their lifestyle. As a result, if VS is increasingly initiated and carried out by those who have basic creature comforts, it may be easier to provide them with a strong foundation of socioeconomic equality than others (a society that is consumptive or lauds consumerism).

Furthermore, the author hopes that there will be legal protection and more councils or bodies in Nauru to deal with consumerism. The legal protection must be enforced so that Nauruans can better comply with the regulations put in place by the government to address this problem, which the author describes as "extremely complicated." For the author, regulating consumerism is a challenge, but it is important to remember that consumerism is a human construct; despite all of the complex factors involved, it must be brought into the realm of benefiting public life, not the other way around.

\section{CONCLUSION}

Consumption has trapped Nauruans, who are lulled by its phosphate resources, according to the case of Nauru, a country that was once very rich and has now turned into the fifth poorest country in the world. The spillover effect occurred as well, beginning with excessive exploration and continuing to have an impact on other things such as the consumerism lifestyle that was overly spoiled by the state; environmental damage; the highest obesity rate in the world; and finally, the 
bankruptcy of a country that was heavily in debt. Those many aspects of consumerism that are harmed are increasingly capable of supporting the author's argument that globalization accelerates consumerism. Globalization allows for the presence of new tools, such as new sales techniques through faster internet media, while also increasingly encouraging a global transformation in seeing needs that are no longer limited to food, clothing, and shelter, but rather to the desire to gain social prestige.

\section{REFERENCES}

Aldino, R. (2016, January 10). Nauru, Negara kaya kini Menderita. Retrieved from Narasi: $\quad$ https://www.hipwee.com/narasi/nauru-negara-kaya-kinimenderita/

Dugis, V. (2018, December 13). Globalisasi dan Konsumerisme. Class lecturing in Isu-Isu Global Kontemporer: Dari Internasionalisme ke Globalisasi. Surabaya.

Etzioni, A. (2004). The Post Affluent Society. Review of Social Economy, 512(3), 407-420.

Gopalan, J. (2017). BMI Boom and Economic Collapse in Nauru. Retrieved from Harvard Politics: http://harvardpolitics.com/world/obesity-in-nauru/

Hallett, V. (2015, September 22). The People of Nauru Want to Get Healthy, so Why Can't They Succeed. Retrieved from NPR Goats and Soda: https://www.npr.org/sections/goatsandsoda/2015/o9/22/442545313/thepeople-of-nauru-want-to-get-healthy-so-why-cant-they-succeed

Jegulo. (2017, November). Sepuluh Fakta Nauru, Negara Kaya Raya yang Kini Jadi Miskin Sedunia . Retrieved from https://www.jegulo.com/2017/11/10fakta-nauru-negara-kaya-raya-yang.html

Migone, A. (2004). Hedonistic Consumerism: From Want-Satisfication to WhimSatisfication. CGPE Working Paper 4/5, 1-26.

Pillsrisetti, J. (2007). The Tragedy of Nauru: A Microcosm of the Conflict between Increasing Resource Exploitation and Sustainability. Small Economies and Global Economics, 1-14.

Pollock, N. J. (2014). Nauru Phosphate History and the Resource Curse Narrative. Le Journal de la Société des Océanistes, 108-120.

Rintoul, I. (2018, August 27). Nauru rushes to demolish refugee tents before Pacific Islands Forum . Retrieved from Refugee Action Coalition SYdney: http://www.refugeeaction.org.au/?p=7049

Stearns, P. N. (2006). Consumerism in World History: The Global Transformation of Desire. New York: Routledge, Taylor \& Francis Group.

Ward, D., \& Lasen, M. (2009). An Overview of Needs Theories behind Consumerism. Munich: MRA Press. 